\title{
Acute toxicity and potentiation of barbiturate-induced sleep in mice orally treated with hydro-alcoholic extract of Cyclolepis genistoides D. Don. (Asteraceae)
}

\author{
Yenny Montalbetti Moreno ${ }^{1 *}$, Derlis A. Ibarrola ${ }^{1}$, Olga Heinichen ${ }^{1}$, Nelson Alvarenga ${ }^{2}$, Julio. H. Dolz Vargas ${ }^{3}$, Maria C. \\ Hellion-Ibarrola ${ }^{1 *}$ \\ 'Departamento de Farmacología, Facultad de Ciencias Químicas, Universidad Nacional de Asunción, Campus UNA, San Lorenzo, Paraguay. \\ ${ }^{2}$ Departamento de Fitoquimica, Facultad de Ciencias Químicas, Universidad Nacional de Asunción, Campus UNA, San Lorenzo, Paraguay. \\ ${ }^{3}$ Departamento de Farmacología, Facultad de Ciencias, Instituto de Farmacia, Escuela de Química y Farmacia, Universidad Austral de Chile, Valdivia, Chile.
}

\begin{tabular}{l}
\hline ARTICLE INFO \\
\hline Received on: 17/08/2018 \\
Accepted on: 15/09/2018 \\
Available online: 30/11/2018 \\
\hline Key words: \\
Cyclolepis genistoides D. \\
Don., Palo azul, LD50, \\
general behavior, sleep time.
\end{tabular}

\begin{tabular}{l}
\hline ABSTRACT \\
The aims of this work were to determine the acute toxicity, the influence on general behavior, motor coordination, \\
barbiturate-induced sleeping time in mice, and the chemical constituents of a hydro-alcoholic extract of the Cyclolepis \\
genistoides D. Don. (Asteraceae) (CE-Cg). The presence of triterpenes, sesquiterpene lactones, and saponins was \\
detected by preliminary phytochemical testing of CE-Cg. No lethal sign was observed up to $3,000.0 \mathrm{mg} / \mathrm{kg}$ (po) or \\
$1,500.0 \mathrm{mg} / \mathrm{kg}$ bw (ip) of CE-Cg administered to mice. Oral doses of $10.0,100.0$, and $1,000.0 \mathrm{mg} / \mathrm{kg}$ bw of the CE-Cg \\
significantly prolong the sleeping time induced by barbiturate and ethyl ether when compared with the control group. \\
Motor coordination performance in rota-rod and chimney test was not modified by oral treatment with CE-Cg (1.0, \\
$10.0,100.0$, and $1,000.0 \mathrm{mg} / \mathrm{kg}$ bw) when compared with the control group. Therefore, based on these findings, we \\
concluded that the hydro-alcoholic extract of the $C$. genistoides $\mathrm{D}$. Don. is safe, well tolerated without disturbing \\
motor coordination orally and shows significant hypnotic property in mice. Consequently, $C$. genistoides is potentially \\
a good candidate to develop a phytotherapeutic agent for a complementary treatment of insomnia and encourages us to \\
pursue specific and complementary chemical and pharmacological evaluation at Central nervous system (CNS) level.
\end{tabular}

\section{INTRODUCTION}

Medicinal plants are therapeutic resources available for most people in developing countries. Despite their traditional use and its high consumption, there are few scientific studies that prove their safety and effectiveness. The scientific information that supports the rational use of medicinal plants by Paraguayans is scarce and a big task should be carried out focusing on the effort

\section{${ }^{*}$ Corresponding Author}

Yenny Montalbetti Moreno, Departamento de Farmacología, Facultad de Ciencias Químicas, Universidad Nacional de Asunción, Campus UNA, San Lorenzo, Paraguay.E-mail: yennymm @qui.una.py;

Maria C. Hellion-Ibarrola, Departamento de Farmacología, Facultad de Ciencias Químicas, Universidad Nacional de Asunción, Campus UNA, San Lorenzo, Paraguay.E-mail: chellion@qui.una.py in education to revert such a situation. Undoubtedly, the arrival of new pharmacological information's will strengthen health benefits to a society accustomed to decades of cultural acceptance of usage of plants for medicinal purpose. Besides, a potential development of innovative products should influence as an attractive factor for social and economic benefits for farmers. A core aspect to improve acceptance that they should be validated pharmacologically in a nearer way of popular usage (CYTED, 1995). Truly, the WHO (2013) recognizes and recommends the pharmacological study and the validation of medicinal plants used for medicinal purpose. Indeed, $80 \%$ of the world population uses traditional medicines for the relief of several diseases, and phytotherapy is expected to play an important role in the therapy of the future. Also, preparations of plant origin have recently increased their presence and sale both in the Pharmacies and Internet, which is a topic of big concern (WHO, 2011). 
Cyclolepis genistoides D. Don. is a shrub of the family of the Asteraceae. Its distribution covers North of Paraguay and Argentina (Chaco region) and probably Bolivian Chaco in its characteristic salt flats environment (Cabrera, 1978; Cabrera and Freire, 1998; Pin et al., 2009). The ethnomedical information indicates that tea or mate (decoction) made from the aerial part of $C$. genistoides D. Don. is used in Argentina and Paraguay as a cough suppressant, slimming, analgesic, antiarthritic, hypoglycemic, antihypertensive, diuretic, and as refreshing in conditions like rheumatism, liver disorders, lumbago, and elimination of uric acid (Filipov, 1994; Giberti, 1983; Gonzalez Torres, 1992; Pin et al., 2009; Ibarrola et al., 2011). Triterpenes and sesquiterpene lactones were reported as component (De Heluani et al., 1997). Concerning the pharmacological activity of $C$. genistoides, it has been reported, among others, an inhibitory activity on alpha-glycosidase (already patented) (Hasegawa, 2005), diuretic, anti-inflammatory activity (Sosa et al., 2007; 2011), analgesic, and muscle relaxing activity (Rondina et al., 2008). Taking into consideration that $C$. genistoides is popularly employed in certain chronic suffering medical conditions (pain, arthritis, rheumatism, diabetes, liver diseases, hypertension, and lumbago) and that information on safety and its effects on CNS is scarce, we propose to evaluate the hypothetical influence on CNS in order to highlight additional properties that contribute to the improvement of life quality of patients (Esteves et al., 2013). We hypothesized that the extracts of aerial parts of $C$. genistoides treatments might effectively modify centrally governed mice behavioral parameters. Therefore, the purpose of this work is to determine acute toxicity, the influence on general behavior, motor coordination, barbiturate-induced sleeping time in mice, and the chemical constituents of a hydro-alcoholic extract of the $C$. genistoides D. Don. (Asteraceae).

\section{MATERIALS AND METHODS}

\section{Plant material and extract preparation}

The aerial parts of $C$. genistoides D. Don. (Asteraceae) (palo azul) were collected in 2012 in Presidente Hayes Department, Paraguay (route N Km 133). A voucher sample of the material was deposited at the Herbarium of Departamento de Botánica de la Facultad de Ciencias Químicas under code CVogt No. 297. Fresh specimens were dried at room temperature and then ground and $300 \mathrm{~g}$ of powder was submitted to hydro-alcoholic extraction with a mixture of 70:30 (ethanol:water) in a water bath for 1 hour with agitation every 10 minutes. The extraction was repeated two times and all the resulting hydro-alcoholic extracts were mixed in the same flask, evaporated under reduced pressure in a rotary evaporator, and finally frozen and lyophilized. A $50.27 \mathrm{~g}$ of lyophilized crude extract powder of aerial part of C. genistoides (CE-Cg) was obtained with an approximate yield of $16.76 \%$. The resulting powder was stored in a desiccator at room temperature and protected from light. This freeze-dried powder was used in all chemical and biological tests.

\section{Reagents and drugs}

All chemical agents used were of analytical grade. Sodium chloride (WAKO Pure Chemical Industries Ltd, Japan), diazepam (Valium Roche Laboratory, Argentina), sodium pentobarbital (Nembutal Abbott Laboratory, Japan), and anhydrous diethyl ether (J.T. Baker, Mexico) were employed. Ethanol was acquired locally and submitted to distillation before use.

\section{Animals}

Swiss albino male mice weighing 25-35 g were used. They were housed in a plastic cage and kept in a room with controlled environment of light/dark cycles (12 hours), temperature $\left(22^{\circ} \mathrm{C}-25^{\circ} \mathrm{C}\right)$, and relative humidity $(50 \%-60 \%)$. The animals received commercial foods and were fasted overnight before the experiments allowing free access to drinking water during the trials. All experiments were performed in agreement with international standards of animal welfare and the protocol which was previously approved by the Bioethical Committee of the Facultad de Ciencias Químicas (code IP-02-12).

\section{Phytochemical analysis}

The CE-Cg analysis was performed using the standard methodology described by Sanabria Galindo (1983) based on a sequence of coloring and/or precipitation reactions typically developed by major chemical groups followed by a thin layer chromatography.

\section{Pharmacological tests}

Acute toxicity

Acute toxicity evaluation was performed using the fixed-dose procedure (FDP) proposed by the British Toxicology Society (1984) and currently included in the OECD (2008) Guide 425 using oral (per oz; po) and intraperitoneal (ip) administration. Swiss albino male mice weighing 25-35 g were dosed in a stepwise procedure, per body weight (bw), using the FDP (500.0, $1,000.0,2,000.0$, and $3,000.0 \mathrm{mg} / \mathrm{kg}$ bw, po and 50.0, 100.0, 500.0 , and $1,000.0 \mathrm{mg} / \mathrm{kg}$ bw, ip of $\mathrm{CE}-\mathrm{Cg}$ ) in different groups of five mice in the search for $\mathrm{LD}_{50}$. The animals were observed for lethality during the first 24 hours and daily for 14 days. After 14 days of observation, mice were euthanized and the internal organs were evaluated macroscopically comparing them with the corresponding organs of the control group.

\section{Influence of $\mathrm{CE}-\mathrm{Cg}$ on general behavior of mice}

Different groups of eight male mice were treated orally with distilled water $(0.1 \mathrm{ml} / 10 \mathrm{~g} \mathrm{bw})$ and different doses of CE$\mathrm{Cg}(1.0,10.0,100.0$, and $1,000.0 \mathrm{mg} / \mathrm{kg} \mathrm{bw})$ and the ethological parameters were respectively recorded in individual sessions/ groups. Each animal was observed individually for 5 minutes at 15 minutes intervals during the first 3 hours (Irwin, 1964). The observation periods were extended at 24,48 , and 72 hours and up to 7 days after the administration of the $\mathrm{CE}-\mathrm{Cg}$. The modifications of humor, conscience, locomotor activity (central or peripheral locomotion), and the autonomic activity by simple and direct observation were registered cataloguing $(0-4+)$ according to the intensity of effect on behaviors.

\section{Influence of CE-Cg on barbiturate-induced hypnosis in mice}

Male mice (25-35 g) were randomly distributed in six groups of 10 animals. One group received distilled water $(0.1 \mathrm{ml} / 10 \mathrm{~g} \mathrm{bw})$ as a control and four groups were treated with CE-Cg $(1.0,10.0,100.0$, and $1,000.0 \mathrm{mg} / \mathrm{kg}$ bw, po). One hour 
after an oral administration, each animal was injected with sodium pentobarbital $40 \mathrm{mg} / \mathrm{kg}$ bw, ip. The sixth group received diazepam $0.5 \mathrm{mg} / \mathrm{kg}$ bw, ip, (positive control for central depressor agent) 20 minutes before the barbiturates as a validation of the method used. The time between injection of the hypnotic agent and the loss of the righting reflex (induction time) and the time for recovery of spontaneous righting reflex (sleep time in minutes) were recorded (Carlini et al., 1986).

\section{Influence of CE-Cg on Diethyl ether-induced hypnosis in mice}

Male mice $(25-35 \mathrm{~g})$ were randomly distributed into six groups of eight animals per dose. One group received distilled water $(0.1 \mathrm{ml} / 10 \mathrm{~g} \mathrm{bw})$ as a control and four groups were treated with CE-Cg (1.0, 10.0, 100.0, and 1,000.0 mg/kg bw, po). One hour after oral treatments, each animal was placed in a transparent acrylic chamber $(30 \mathrm{~cm}$ long $\times 15 \mathrm{~cm}$ high $\times 15 \mathrm{~cm}$ wide $)$ closed hermetically and saturated with diethyl ether. The saturation was achieved by wetting a cotton ball of $3 \mathrm{~g}$ with $5 \mathrm{ml}$ of diethyl ether 10 minutes before placing the animal into the chamber. As soon as the acrylic chamber was saturated, the animal is placed into it (individual timing session) and the time of latency and duration of diethyl ether hypnosis were registered. When the animal loss the postural reflex, 60 seconds is waited to remove it from the chamber and placed it in supine position quickly until a complete recovery of spontaneous normal posture (awake) is denoted. Induction time and the duration of hypnosis were registered for each animal. The sixth group received diazepam $0.5 \mathrm{mg} / \mathrm{kg}$ bw, ip, (positive control for central depressor agent) 20 minutes prior to be submitted to the same treatment into the cubicle (Chambers et al., 1978).

\section{Influence of $\mathrm{CE}-\mathrm{Cg}$ on motor performance of mice in rota-rod test}

Twenty-four hours before the experiment, male mice (25-35 g) were submitted to two successive trials (1 minute duration sessions) and those animals remaining in the spinning rod (12-rpm and divided in six equal compartments) were selected and randomly allocated into six different groups $(n=6$ each). Five groups were treated orally with 1.0, 10.0, 100.0, and $1,000.0 \mathrm{mg} / \mathrm{kg}$ bw of $\mathrm{CE}-\mathrm{Cg}$ and vehicle (distilled water, 0.1 $\mathrm{ml} / 10 \mathrm{~g} \mathrm{bw}$ ), respectively. Fifty-five minutes after oral treatment, the animals were placed on the rota-rod for 1 minute session. The time of permanence and number of fall from the spinning rod were registered (in seconds). Three redirections to the bar (maximum) were allowed during the test. The sixth group received diazepam $0.5 \mathrm{mg} / \mathrm{kg}$ bw, ip (positive control) and 20 minutes later was submitted to same procedure to validate the method (De Lima, 2002; Dunham and Miya, 1957).

\section{Influence of $\mathrm{CE}-\mathrm{Cg}$ on motor performance of mice in chimney assay}

The chimney test consists of a glass tube of $25 \mathrm{~cm}$ long $(2.5-3 \mathrm{~cm}$ in diameter) with a reference mark at $10 \mathrm{~cm}$ of one extremity. Briefly, the procedure consists of introducing the animal into horizontally positioned glass tube (marked side) and allowing the free movement of animal up to the opposite end and immediately the tube is placed in the vertical position and the time that it takes the mouse to reach the reference mark, climbing in reverse, is registered. Five different groups of selected male mice $(25-35 \mathrm{~g})$ received oral doses of $1.0,10.0$,
100.0 , and $1,000.0 \mathrm{mg} / \mathrm{kg}$ bw of the CE-Cg and vehicle (distilled water, $0.1 \mathrm{ml} / 10 \mathrm{~g} \mathrm{bw}$ ). Fifty-five minutes later, the animals were subjected to testing in individual sessions and the times were recorded and tabulated conveniently. The positive control group received diazepam $0.5 \mathrm{mg} / \mathrm{kg}$ bw, ip and subjected to the same test after 20 minutes (Boissier and Simon, 1962).

\section{Statistical analysis}

The results were expressed as the mean \pm standard deviation (SD) and statistical analysis of data was performed using analysis of variance (ANOVA) followed by the Dunnett's multiple comparison test using GraphPad Prism 5.0 (GraphPad Software, Inc., CA). The level of probability ( $p$ ) less than 0.05 was considered as statistically significant.

\section{RESULTS AND DISCUSSION}

\section{Qualitative phytochemical profile}

The preliminary phytochemical analysis of $\mathrm{CE}-\mathrm{Cg}$ reveals the presence of several compounds, such as triterpenes, sesquiterpenic lactones, and saponins; however, negative results for the presences of tannins, alkaloids, anthraquinones, steroids, coumarins, flavonoids, and cardiotonic glycosides were obtained. De Heluani et al. (1997) had found similar compounds in $\mathrm{CHCl} 3$ extract except for the saponins. As extraction procedure is diverse in literature, indeed miscellaneous chemical entities and biological activities would be denoted.

\section{Acute toxicity and effects of CE-Cg on general behavior of mice}

Oral and intraperitoneal administration of $\mathrm{CE}-\mathrm{Cg}$ up to $3,000.0 \mathrm{mg} / \mathrm{kg}$ bw and up to $1,000.0 \mathrm{mg} / \mathrm{kg}$ bw, respectively, induced no lethality in mice observed during 24 hours or seven subsequent days. Treatment with doses of $1.0,10.0,100.0$, and $1,000.0 \mathrm{mg} / \mathrm{kg}$ bw, po of the CE-Cg did not cause significant changes in ethological parameters analyzed. However, an increase in motility, respiratory rate, and self-cleaning behavior after 30 minutes of treatment was observed in comparison with the vehicle (water distilled $0.1 \mathrm{ml} / 10 \mathrm{~g} \mathrm{bw}$ ) treated group. After this period, the influence of $\mathrm{CE}-\mathrm{Cg}$ on the mentioned parameters disappears quickly.

Indeed, C. genistoides D. Don. (CE-Cg) exhibits low acute toxicity, reflected by the lack of lethality of all single doses (oral or intraperitoneal) tested and observed within 24 hours period. Besides, in extended observation periods ( 7 days) were not denoted a delayed sub-acute toxic symptom. Acute toxicity quantifies the adverse events occurring within a short period of time subsequent to the single or multiple dose administration of agents tended to be used as medicine and is very important and relevant information as the first stage of toxic evaluation of chemicals (CYTED, 1995; OECD, 2008; Stallard and Whitehead, 2004). Further, macroscopic evaluation of internal organs, such as liver, heart, brain, and kidney in mice treated with the increasing doses of $\mathrm{CE}-\mathrm{Cg}$, denoted no modification in organ integrity in comparison with those matching structures from the control group. This suggests that all single doses up to 3,000 (po) and $1,000 \mathrm{mg} / \mathrm{kg}$ bw (ip), respectively, are not toxic in mice. However, it is proposed that additional toxicological studies should be performed either in non-rodent species or humans to assure a complete toxicological profile of this natural resource. 


\section{Effect of the CE-Cg on barbiturate-induced hypnosis}

Oral treatments with CE-Cg $\left(10.0 \mathrm{mg} / \mathrm{kg}:{ }^{*} p<0.05\right.$; $100.0 \mathrm{mg} / \mathrm{kg}$ : $* * * p<0.001$; and $1,000.0 \mathrm{mg} / \mathrm{kg}$ bw: $* * p<0.01)$ significantly prolonged the sleep time induced by barbiturate between $40 \%$ and $70 \%$ when compared with the vehicle group. However, paradoxically, the oral dose of $1.0 \mathrm{mg} / \mathrm{kg} \mathrm{bw}$ $(* * * p<0.001)$ of the CE-Cg produced a shortening of the sleeping time in comparison with the vehicle group. Diazepam $0.5 \mathrm{mg} /$ $\mathrm{kg}$ bw, ip $(* * * p<0.001)$ was used as a positive control which increases clearly the sleeping time by depressing central nervous system validating the method used (Fig. 1). The induction time was not affected by each treatment (data are not presented).

This study shows that CE-Cg exhibits a week central depressant effect on mice. Certainly, the barbiturate-induced hypnosis is a very useful and sensitive procedure to reveal both CNS stimulating or depressant effects caused by drugs administered to animals (Carlini et al., 1986). Higher doses of CE-Cg (10.0-1,000.0 mg/kg bw), orally administered, clearly induce an increase in the sleeping time of mice. However, the lower dose $(1.0 \mathrm{mg} / \mathrm{kg} \mathrm{bw})$ does the opposite one. The elongation of sleeping time may be due to either by a direct additive depressant effect to the hypnotic effect of barbiturate or by inhibition of the metabolism of the barbiturate, mediated by the oxidative CYP450 system. To elucidate which of these mechanisms are involved in this biological response induce by $\mathrm{CE}-\mathrm{Cg}$, we have performed a diethyl ether-induced hypnosis (see below).

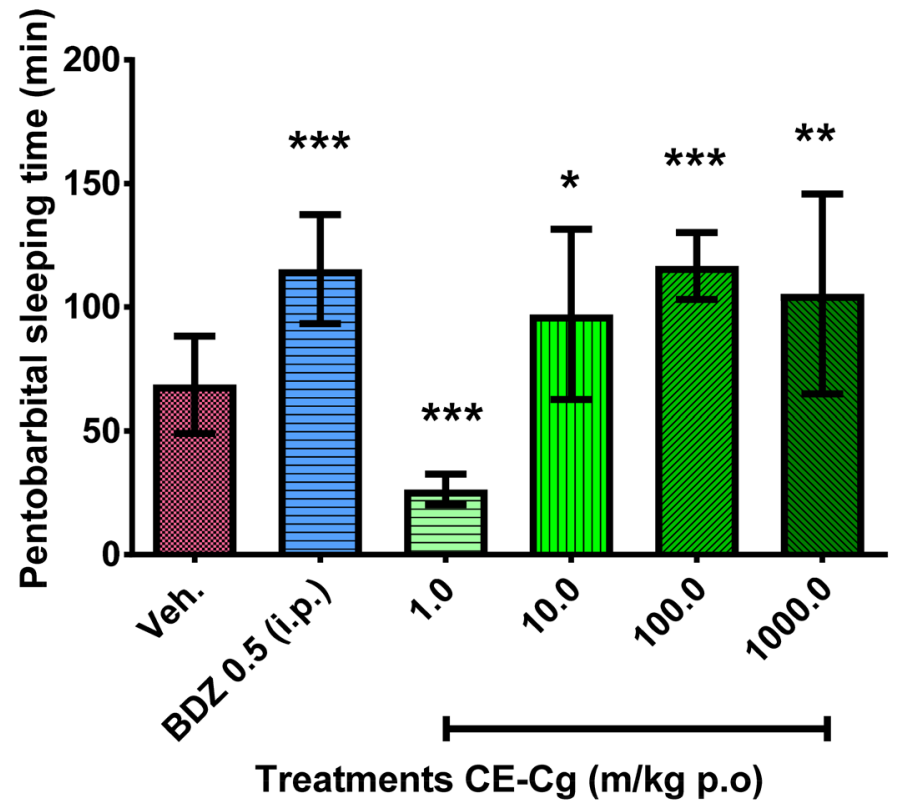

Figure 1. Influence of the CE-Cg administered orally in doses of 1.0, 10.0, 100.0 , and $1,000.0 \mathrm{mg} / \mathrm{kg}$ bw on sleeping time, in minutes, induced by sodium pentobarbital in mice. Each bar represents the mean $\pm \operatorname{SD}(n=10)$. Note that $1.0 \mathrm{mg} / \mathrm{kg}$ produced a shortening of the sleeping time, whereas a dose of 10.0 , 100.0 , and $1,000.0 \mathrm{mg} / \mathrm{kg}$ induced an opposite effect (prolongation of sleeping time) similarly to diazepam (positive control). Statistical analysis was performed using ANOVA followed by Dunnett's multiple comparison test. ${ }^{* *} p<0.001$; ${ }^{* *} p<0.01 ; * p<0.05$ significantly different from vehicle. The induction time was not affected by each treatment (data are not presented).

\section{Effect of the CE-Cg on ethyl ether-induced hypnosis}

Oral treatments with CE-Cg $(1.0, * p<0.05 ; 10.0$, $* * * p<0.001 ; 100.0, * * * p<0.001$; and $1,000.0 \mathrm{mg} / \mathrm{kg}$ bw $* * p$ $<0.01)$ significantly prolonged the sleep time induced by ethyl ether between $40 \%$ and $90 \%$ when compared with the vehicle group. As explained previously, diazepam $0.5 \mathrm{mg} / \mathrm{kg}$ bw, ip (***p $<0.001$ ) was used as a positive control (Fig. 2). The induction time was not affected by each treatment (data are not presented)

Diethyl ether is a central depressant agent which is not metabolized by the oxidative CYP450 system (De Lima, 2002). Indeed, the use of this trial showed that oral administration of C. genistoides induced elongation of the hypnosis in the same direction and dose range, confirming a central depressor effect of $\mathrm{CE}-\mathrm{Cg}$. The results undoubtedly indicate that $\mathrm{CE}-\mathrm{Cg}$ has a depressant effect on central structures governing the balance between the awake-sleep states either in the ascending reticular activating system or other related centers. Nevertheless, the mechanism of this effect is unknown and its discernment will require further complementary studies.

Effect of the CE-Cg on motor performance of mice in rota-rod and the chimney assay

CE-Cg (1.0, 10.0, 100.0, and 1,000.0 mg/kg bw), administered orally, did not affect motor coordination of mice submitted to the spinning rod when compared with the vehicle control group (Fig. 3). Similar results were obtained in the chimney test in all doses used (Fig. 4) and diazepam was employed in nonsedative dose as a positive control $(0.5 \mathrm{mg} / \mathrm{kg}$ bw, ip).

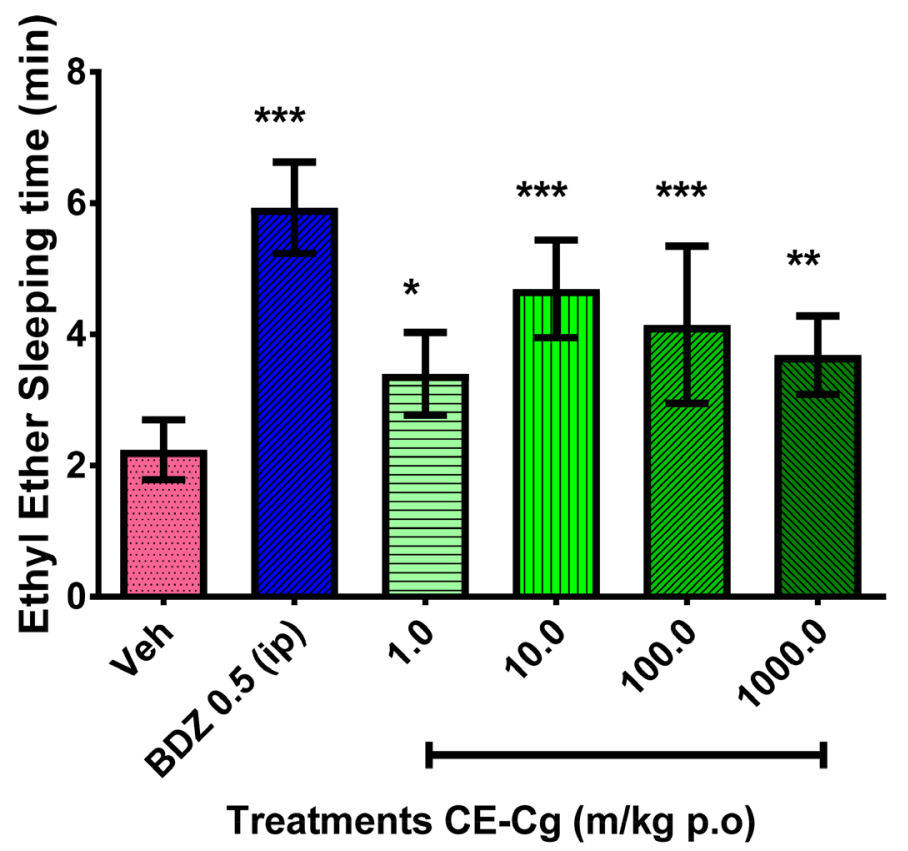

Figure 2. Influence of the CE-Cg administered orally in doses of 1.0, 10.0, 100.0 , and $1,000.0 \mathrm{mg} / \mathrm{kg}$ bw on sleeping time, in minutes, induced by diethyl ether in mice. Each bar represents the mean $\pm \mathrm{SD}(n=8)$. All doses used were able to increment the diethyl ether-induced hypnosis. Statistical analysis was performed using ANOVA followed by Dunnett's multiple comparison test. ${ }^{* *} p$ $<0.001 ; * * p 0.01 ; * p<0.05$ significantly different from vehicle. 
Motor coordination is one of the physiological parameters finely regulated by CNS and can be modified by several kinds of centrally acting agent. Both, the rota-rod and chimney assays, are a different and sensitive way to visualize any modification of motor coordination induced by drugs. Likewise, these findings are complementary with a lack of toxicity and weak influence of CE$\mathrm{Cg}$ on general behavior denoted in mice that potentially account for a safe product used in Paraguayan traditional medicine.

In literature are increasing new information on the metabolic effects of semi-purified or purified compounds (oleanolic acid, deacylcynaropicrin, etc.) from C. genistoides. Thus, antidiabetic effect in rats (Wang et al., 2011), anti-inflammatory effect (Sosa et al., 2011) in mice, an alpha glycosidase inhibitory activity (Hasegawa, 2005), increase of muscle mass and improvement of insulin resistance via PPAR $\gamma$ activation (Sato et al., 2013; 2016), suppression of obesity-associated inflammation (Sung et al., 2010), and a weak diuretic effect in rats were reported (Sosa et al., 2007) with purified or crude extract of C. genistoides where flavonoid was detected. Definitively, results on acute toxicity or CNS effect are clearly scarce. Accordingly, these results are markedly relevant new information and probably involve or not to flavonoids. Meanwhile, extraction procedure, the biological system used, and dose/route/duration of treatments are factors disturbing, respectively, composition quality of yielded secondary metabolites and the final biological response. Consequently, based on this report, our present results suggest that a rational experimental method should consider this point to avoid the appearance of disturbing inconsistencies in the results.

Finally, our studies span the potentiality of $C$. genistoides as a candidate for the development of a safety sedative agent that may reside or not in molecules such as oleanolic acid and

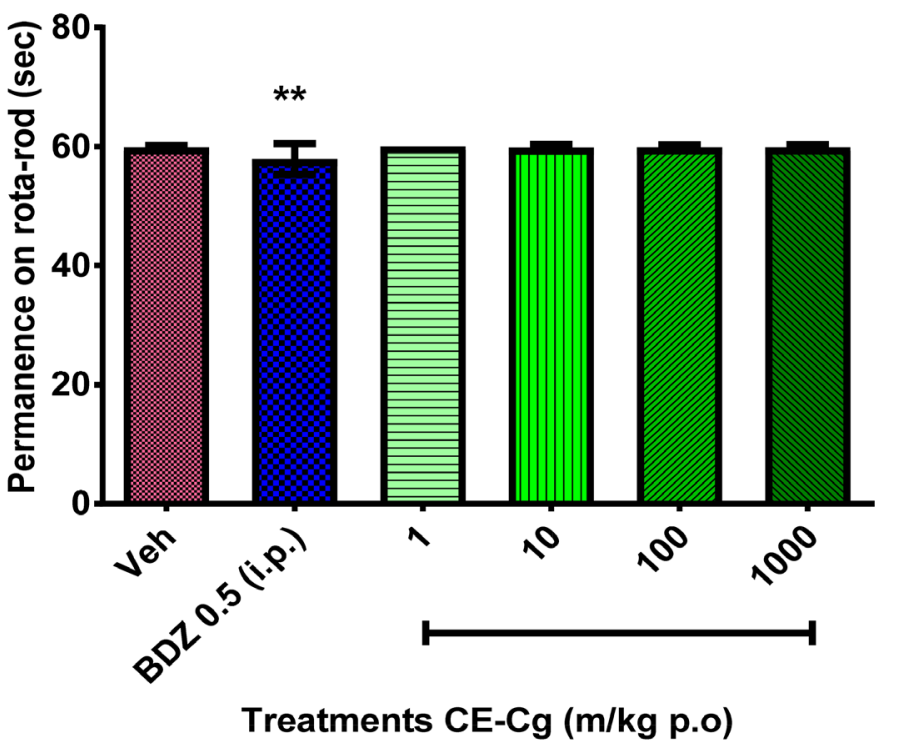

Figure 3. Influence of the CE-Cg administered orally in doses of 1.0, 10.0, 100.0 , and $1,000.0 \mathrm{mg} / \mathrm{kg}$ bw on mice motor coordination and the time spent in the spinning rod and compared with the vehicle. None doses of $\mathrm{CE}-\mathrm{Cg}$ used altered mice performance in this assay, whereas diazepam $(0.5 \mathrm{mg} / \mathrm{kg}$ ip, positive control) significantly increased the number of falls as expected (**p $>$ $0.01)$. Each bar represents means $\pm \mathrm{SD}(n=8)$ and the statistical analysis was performed using ANOVA followed by Dunnett's multiple comparison test. ${ }^{* *} p$ $<0.01$ significantly different from vehicle.

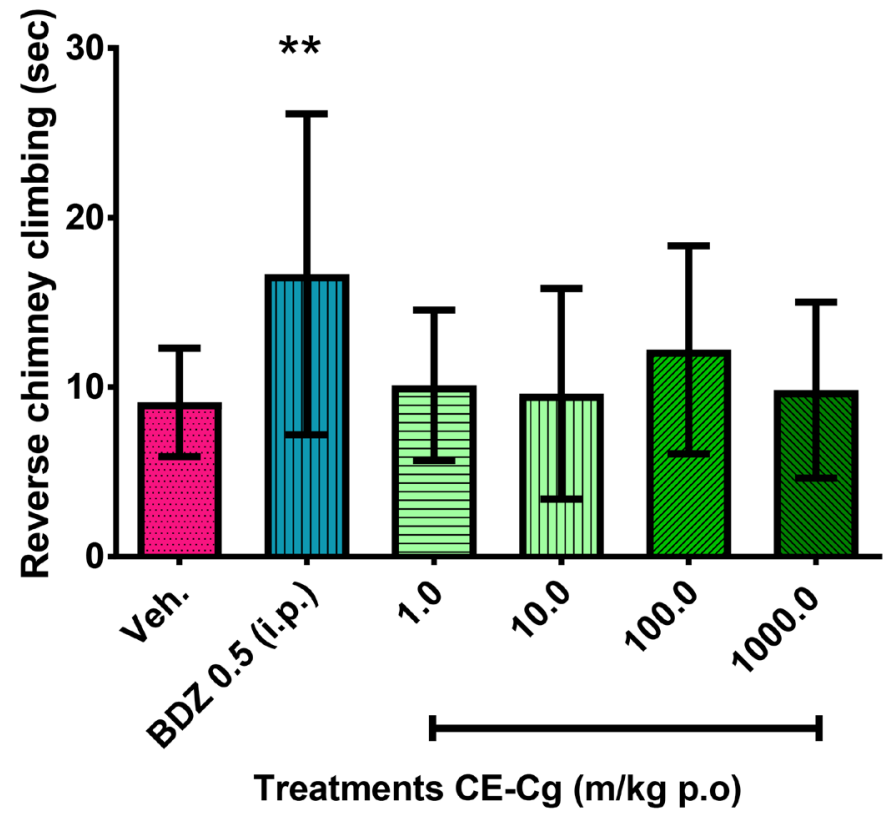

Figure 4. Influence of the CE-Cg administered orally in doses of 1.0, 10.0, 100.0 , and $1,000.0 \mathrm{mg} / \mathrm{kg}$ bw on mice submitted to the chimney test and compared with the vehicle. Each bar represents the mean $\pm \operatorname{SD}(n=12)$. None doses of CE-Cg used altered the time spent in reverse climbing in the chimney test, whereas diazepam $(0.5 \mathrm{mg} / \mathrm{kg}$ ip, positive control) significantly increased the time spent in reverse climbing as expected $(* * p>0.01)$. Statistical analysis was performed using ANOVA followed by Dunnett's multiple comparison test. $*^{*} p<0.01$ significantly different from vehicle.

deacylcynaropicrin or the interaction of components from crude extract. Indeed, these differences are important factors affecting toxicity and biological activity and will need a specific attention so as to clarify chemical compositions that are linked to specific activities and may account for a possible secure employment in the human population.

\section{CONCLUSION}

Based on results, we concluded that $C$. genistoides exhibits a potentially useful weak depressant effect on CNS (sedative-like) in mice. Besides, a low acute toxicity revealed by the non-appearance of toxic symptoms, no modification of general behavior, and motor coordination of mice after oral treatment strengthen these outcomes. Together, all this new information encourages us to pursue specific and complementary chemical and pharmacological evaluation at the CNS level.

\section{ABBREVIATIONS \\ CE-Cg = Crude extract of Cyclolepis genistoides; Per oz $=$ oral route (p.o.); \\ po = Intraperitoneal; \\ bw $=$ body weight.}

\section{ACKNOWLEDGMENTS}

This research work was performed under the financial support of Facultad de Ciencias Químicas de la Universidad Nacional de Asunción. We want to thank, respectively, to Departamento de Botánica and Departamento de Fitoquimica from Facultad de Ciencias Químicas for supporting us with 
the identification of plant material and preliminary chemical evaluation of the extract obtained.

\section{CONFLICT OF INTEREST}

All authors have none to declare.

\section{REFERENCES}

Boissier JR, Simon P. La reaction d'exploration chez la souris. Therapie, 1962; 17:1225-32.

British Toxicology Society Working Party on Toxicity. Special report: a new approach to the classification of substances and preparations on the basis of their acute toxicity. Hum Toxicol, 1984; 3(2):85-92.

Cabrera AL. 1978. Flora de la Provincia de Jujuy: República Argentina Vol. X, 590-592

Cabrera AL, Freire SE. Flora del Paraguay Compositae V Conservatoire et jardin botaniques de la Ville de Genève. Missouri Botanical Garden, 1998; 27:118-21.

Carlini EA, Contar JDP, Silva-Filho AR, Silveira-Filho NG, Frochtengarten ML, Bueno OFA. Pharmacology of lemongrass (Cymbopogon citratus Stapf) I Effects of teas prepared from the leaves on laboratory animals. J Etnopharmacol, 1986; 17(1):37-64.

Chambers DM, Jefferson GC, Ruddick CA. Halothane-induced sleeping time in the mouse: its modification by benzodiazepines. Eur J Pharmacol, 1978; 50(2):103-12.

CYTED. Manual de Técnicas de Investigación: Subprograma X: Química Fina Farmacéutica. Proyecto X-1: Búsqueda de Principios Bioactivos en Plantas de la Región. Programa Iberoamericano de Ciencia y Tecnología para el Desarrollo. Editor: CYTED, Madrid, España, 1995.

De Heluani CS, De Boggiato MV, Catalan CAN, Díaz JG, Gedris TE, Herz W. Triterpenes and sesquiterpene lactones from Cyclolepis genistoides. Phytochemistry, 1997; 45(4):801-5.

De Lima TCM. Evaluación de la actividad y desempeño motor. In: Lapa AJ, Souccar C, Lima-Landman MTR, Monteiro de Lima TC (eds.). Métodos de Evaluación de la Actividad Farmacológica de Plantas Medicinales. Editograf, CYTED/CNPq, Florianópolis, Brasil, pp 78-9, 2002.

Dunham NW, Miya TS. A note on to simple apparatus for detecting neurological deficits in rats and mice. J Amer Pharm Assoc, 1957; 46:208-10.

Esteves JE, Wheatley L, Mayall C, Abbey H. Emotional processing and its relationship to chronic low back pain: Results from a case-control study. Manual Ther, 2013; 18(6):541-6.

Filipov A. Medical plants of the Pilagá of central Chaco. J Ethnopharmacol 1994; 44(3):181-93.

Giberti GC. Herbal Folk Medicine in Northwestern Argentina: Compositae. J Ethnopharmacol, 1983; 7(3):321-41.

González Torres DM. Catálogo de Plantas Medicinales (y Alimenticias y Útiles) usadas en Paraguay, Ed. El País Asunción, Paraguay, p 322.

Hasegawa H. Alpha glucosidase inhibitor comprising Palo Azul as active ingredient. Patent Abstracts of Japan, Bibliographic data: JP2005263629 (A)-2005-09-29. Available via https://worldwide. espacenet.com/publicationDetails/biblio? CC $=\mathrm{JP} \& \mathrm{NR}=$ $2005263629 \& \mathrm{KC}=\& \mathrm{FT}=\mathrm{E} \&$ locale $=$ en $\mathrm{EP} \#$

Ibarrola D, Degen R, Ferro EA, Alvarenga N, Ibarrola-Hellion MC. Catalogo Illustrado de 80 plantas medicinales del Paraguay. 1st edition, Facultad de Ciencias Químicas, Universidad Nacional de Asunción and Agencia de Cooperación International del Japón (JICA), Asunción, Paraguay, pp 125-6, 2011.

Irwin S. Drug screening and evaluation of new compounds in animals. In: Nodine JH, Siegler PE (eds.). Animal and pharmacologic techniques in drug clinical evaluation. 1st edition, Year Book Medical Publischers Inc., Chicago, IL, pp 36-54, 1964.

OECD. Test No. 425: acute oral toxicity: up-and-down procedure, OECD guidelines for the testing of chemicals, Section 4. OECD Publishing, Paris, France, 2008. Available via https://doi.org/10.1787/9789264071049-en Pin A, González G, Marin G, Céspedes G, Cretton S, Christen P, et al. Plantas Medicinales del Jardín Botanico de Asuncion. Editoras: Ana Pin y Gloria Céspedes. Financiamiento: Municipalidad de Asunción, Municipalidad de Ginebra, Conservatorio y Jardín Botánicos de Ginebra Suiza y la Asociación Etnobotánica Paraguaya. Editorial AGR Servicios Gráficos. Primera Edición, p 224, 2009.

Rondina R, Bandoni AL, Coussio JD. Especies medicinales Argentinas con potencial actividad analgésica. Dominguezia, 2008; 24(1):47-69.

Sanabria-Galindo A. Análisis fitoquímico preliminar: metodología y su aplicación en la evaluación de 40 plantas de la familia Compositae. Departmento de Farmacia, Facultad de Ciencias, Universidad Nacional de Colombia, Bogotá, Colombia, pp 62-77, 1983.

Sato H, Ishikawa M, Funaki A, Kimura Y, Yoshida H, Fukata H, Hasegawa H, Ueno K. Cyclolepis genistoides D. Don (palo azul) promotes differentiation of adipocytes and regulates adipokine expression. Nutr Res, 2013; 33(11):922-31

Sato H, Funaki A, Kimura Y, Sumitomo M, Yoshida H, Fukata $\mathrm{H}$, Ueno K. Ethanol extract of Cyclolepis genistoides D. Don (palo azul) induces formation of myotubes, which involves differentiation of $\mathrm{C} 2 \mathrm{C} 12$ myoblast cells. Nutr Res, 2016; 36(7):731-41.

Sosa A, Fusco MR, Petenatti ME, Juarez A, Del Vitto LA, Petenatti E. Estudios farmacognósticos y farmacológicos comparativos sobre tres especies diuréticas de amplio uso popular en el centro-oeste argentino. Bol Latinoam Caribe, 2007; 6(6):386-7.

Sosa A, Fusco MR, Rossomando P, Juárez A, Robles S, Petenatti E, Pelzer L. Anti-inflammatory properties from isolated compounds of Cyclolepis genistoides. Pharm Biol, 2011; 49(7):675-8.

Stallard N, Whitehead A. A statistical evaluation of the fixed dose procedure. Alter Lab Anim, 2004; 32 Suppl 2:13-21.

Sung HY, Kang SW, Kim JL, Li J, Lee ES, Gong JH, Peng J, Cao PP, Liang X, Hai CX. Oleanolic acid reduces markers of differentiation in 3T3-L1 adipocytes. Nutr Res, 2010; 30(12):831-9.

Wang X, Li YL, Wu H, Liu JZ, Hu JX, Liao N, et al. Antidiabetic effect of oleanolic acid: a promising use of a traditional pharmacological agent. Phytother Res, 2011; 25(7):1031-40.

WHO. Safety and security on the Internet: challenges and advances in Member States: based on the findings of the second global survey on e-Health. (Global Observatory for e-Health Series, v. 4). Available via http://www.who.int/goe/publications/ehealth_series_vol4/en/

WHO. Traditional medicine strategy: 2014-2023. World Health Organization, 2013. Available via http://www.who.int/medicines/ publications/traditional/trm_strategy14_23/en/

How to cite this article:

Montalbetti Y, Ibarrola DA, Heinichen O, Alvarenga N, Dolz-Vargas JH, Hellion-Ibarrola MC. Acute toxicity and potentiation of barbiturate-induce sleep in mice orally treated with hydro-alcoholic extract of Cyclolepis genistoides D. Don. (Asteraceae). J App Pharm Sci, 2018; 8(11): 042-047 